\title{
Regional distribution of mercury in sediments of the main rivers of French Guiana (Amazonian basin)
}

\author{
Valérie Laperche ${ }^{1 *}$, Jennifer Hellal ${ }^{1}$, Régine Maury-Brachet ${ }^{2}$, Bernard Joseph $^{3}$, Pierre Laporte ${ }^{3}$, \\ Dominique Breeze ${ }^{1}$ and François Blanchard ${ }^{1}$
}

\begin{abstract}
Use of mercury ( $\mathrm{Hg}$ ) for gold-mining in French Guiana (up until 2006) as well as the presence of naturally high background levels in soils, has led to locally high concentrations in soils and sediments. The present study maps the levels of $\mathrm{Hg}$ concentrations in river sediments from five main rivers of French Guiana (Approuague River, Comté River, Mana River, Maroni River and Oyapock River) and their tributaries, covering more than $5450 \mathrm{~km}$ of river with 1211 sampling points. The maximum geological background Hg concentration, estimated from 241 non-gold-mined streams across French Guiana was $150 \mathrm{ng} \mathrm{g}^{-1}$. Significant differences were measured between the five main rivers as well as between all gold-mining and pristine areas, giving representative data of the $\mathrm{Hg}$ increase due to past gold-mining activities.

These results give a unique large scale vision of $\mathrm{Hg}$ contamination in river sediments of French Guiana and provide fundamental data on $\mathrm{Hg}$ distribution in pristine and gold-mined areas.
\end{abstract}

Keywords: Mercury; French Guiana; Sediments; Gold-mining

\section{Introduction}

A clear link has been established between mercury $(\mathrm{Hg})$ contamination in the Amazon region and gold mining activities due to the use of metallic $\mathrm{Hg}$ in the mining process (Veiga et al. 1999), however, in some cases, the link between $\mathrm{Hg}$ contamination (soil, sediment, fish or human) and gold mining is not always clear. For example, Quenel et al. (2007) found high levels of $\mathrm{Hg}$ in the hair of the Amerindian population of Trois Sauts in the upper Oyapock River (French Guiana); yet there is no gold mining in this area. Prior to Quenel's study, $\mathrm{Hg}$ contamination has also been reported in riparian populations in remote areas of the upper Negro River (SilvaForsberg et al. 1999), the Tapajos River (Castilhos et al. 1998), the Apiacas Reserve (Barbosa et al. 1997) and the Amapas (Bidone et al. 1997).

$\mathrm{Hg}$ concentrations in Amazonian soils are often high, even in areas far from anthropic sources (Roulet et al.

\footnotetext{
* Correspondence: v.laperche@brgm.fr

'BRGM, D3E, Water, Environment and Ecotechnology Division, 3 avenue Claude Guillemin, BP 36009, 45060 Orléans, France

Full list of author information is available at the end of the article
}

1998; Lechler et al. 2000; Fadini and Jardim 2001, De Oliveira et al. 2001).

Lithogenic $\mathrm{Hg}$ accumulates in soil due to the release of more mobile elements during the weathering of source rocks (iron oxides) (Grimaldi et al. 2001 Roulet et al. 1998). The age of tropical soils (several million years; very high compared to the ages of soils in temperate areas) amplifies this phenomenon. Atmospheric $\mathrm{Hg}$ results from degassing of the Earth's crust via the oceans and volcanoes, and is deposited on the top soil either directly or after canopy leaching (Mason et al. 1994). Lithogenic and atmospheric $\mathrm{Hg}$ stored in soil are primarily present in a divalent form $(\mathrm{Hg}(\mathrm{II}))$ (Schuster 1991).

One of the main sources of anthropic $\mathrm{Hg}$ is metallic $\mathrm{Hg}$ which is used to amalgamate gold in gold mining processes. In 2005, in French Guiana, the gold production came for a quarter from primary gold ores (for 4 extraction sites only) and three quarters from alluvial placer deposits. At this time all mining techniques used $\mathrm{Hg}$ in the process (since 01/01/2006 the use of $\mathrm{Hg}$ is banned in France). Picot et al. (1993) estimated a $\mathrm{Hg} / \mathrm{Au}$ ratio of 1.37 . Using this ratio and the quantity of gold 
declared in 2005, the total losses of $\mathrm{Hg}$ can be estimated to be around $286 \mathrm{~T}$ in French Guiana.

$\mathrm{Hg}$ is present in river waters in very low concentrations, much lower than the French drinking water standards $\left(1 \mu \mathrm{g} \mathrm{L}^{-1}\right)$ or the Maximum Contaminant Level (MCL) of $2 \mu \mathrm{g} \mathrm{L}^{-1}$ (EPA), and presents no risk for direct consumption or for swimming. Moreover, $99 \%$ of the $\mathrm{Hg}$ present in Guiana river water is in the inorganic form (Boudou et al. 2006; Sampaio Da Silva et al. 2009; Roulet et al. 1999). However, inorganic Hg may be converted to organic forms (methylated forms such as monomethylmercury: $\mathrm{MMHg}$ ), which are highly toxic and potential neurotoxins (World Health Organisation WHO 1990). Conversion to $\mathrm{MMHg}$ is generally a microbial process, through the action of sulfate or iron reducing bacteria (Compeau and Bartha 1985; King et al. 2002; Fleming et al. 2006). Hg biomagnification along the food webs, principally based on cumulative transfers of the methylated form, can lead to extremely high $\mathrm{Hg}$ concentrations in piscivorous species at the top of the trophic networks (Boudou and Ribeyre 1997; Morel et al. 1998). Soil erosion also contributes to contaminating the food chain by transporting high quantities of $\mathrm{Hg}(\mathrm{II})$ associated with particles towards bottomlands and rivers, where biogeochemical conditions favor $\mathrm{Hg}$ methylation (Morel et al. 1998; Ullrich et al. 2001).

In 1994, the French National Public Health Network (InVS) reported significant $\mathrm{Hg}$ exposure of native Amerindians in French Guiana through fish consumption (Cordier et al. 1997). In response, InVS, in collaboration with the National Scientific Research Center (CNRS) and the health authorities, launched several studies which main objectives were to (i) quantify $\mathrm{Hg}$ intake with food and (ii) identify the principal fish species with the highest $\mathrm{Hg}$ levels. The overall river contamination, notably sediments, was not considered in these studies.

In 2004, a monitoring program (Regional distribution of mercury in sediments and fishes of six rivers of French Guiana) was established in order to assess $\mathrm{Hg}$ contamination of the human populations of French Guiana. This program aimed to generate a database of $\mathrm{Hg}$ concentrations in sediments and fish covering as much of the territory of French Guiana as possible. The project focused on total $\mathrm{Hg}$ concentrations. Indeed, 97 to $100 \%$ of $\mathrm{Hg}$ in fish is under the MMHg form and thus is equivalent to total $\mathrm{Hg}$ contents (Maury-Brachet et al. 2006). Sediment sampling and analyses $(n=1211)$ were carried out by the BRGM (this study) on five of the six Rivers, while the CNRS focused on $\mathrm{Hg}$ concentrations in fish $(\mathrm{n}=974)$ in all six rivers. The originality of this study lies in its large scale regional approach whereas most of the previous studies are focused on one site or river. Moreover, the use of the same sampling strategy and analytical method on all samples enables data comparison over the whole study area. This study presents results of total $\mathrm{Hg}$ in sediments and compares them with values measured in other Amazonian regions to distinguish the anthropogenic impact from the natural background level. The final goal was to establish, on the scale of French Guiana, a Hg contamination map, usable by the Guyanese community to take into account environmental impacts in the development of French Guiana.

\section{Methods}

\section{Study area}

French Guiana is situated in northern South America within $2-6^{\circ} \mathrm{N}$ and $51^{\circ} 30^{\prime}-54^{\circ} 30^{\prime} \mathrm{W}$ with Surinam to the west, Brazil to the east and south and the Atlantic Ocean to the north (Figure 1). The total area of $87500 \mathrm{~km}^{2}$ (Collectif 2002) is approximately $96 \%$ tropical rainforest. Most of the gold deposits are epigenetic, sited in the proximity of major geological structures, and linked to low and medium metamorphic grade granitoid-greenstone belts (Milesi et al. 1995; Voicu et al. 2001). Weng et al. (2006) established a map of the potential maximum surface touched by the gold bearing extraction by taking into account parameters such as the geological data, the map of the known gold mining sites (BRGM Inventory of the mining resources of the French territory, 1970-1995) and the ancient and recent placer mining (legal and illegal). These areas cover a total surface of almost 29 $000 \mathrm{~km}^{2}$ (Figure 1), there are two large bands parallel to the coast, one from Saint George to Saint Laurent and the second from Camopi to Grand Santi.

\section{Sampling area and method}

The geographical sectors studied cover most of the hydrographical axes of French Guiana navigable by a motorboat, including their tributaries, whether they are gold mined or not, in order to be able to distinguish the natural geochemical background from the anthropogenic activities. This study systematically sampled all the representative lithologies of French Guiana to compare the Hg levels in mined areas to pristine areas. From September 2005 to November 2006, 1211 samples were collected along approximately $5450 \mathrm{~km}$ of five main rivers (Approuague River, Comté River, Mana River, Maroni River and Oyapock River) and theirs tributaries. Sampling locations were semi-uniformly spaced at approximately 1, 5 or $10 \mathrm{~km}$ intervals. The spacing between sampling sites was defined to allow the collection of a maximum number of samples in the available time. The $1 \mathrm{~km}$ step was used for the zones of increased interest (vicinity of villages or communes, gold mining sites and at the mouths of tributary's draining basins characterized by extensive mining operations); the $5 \mathrm{~km}$ step was adopted in all other sectors. Exceptionally, a step of $10 \mathrm{~km}$ was used in the estuaries of the large rivers (zones generally subjected to the tide). The 


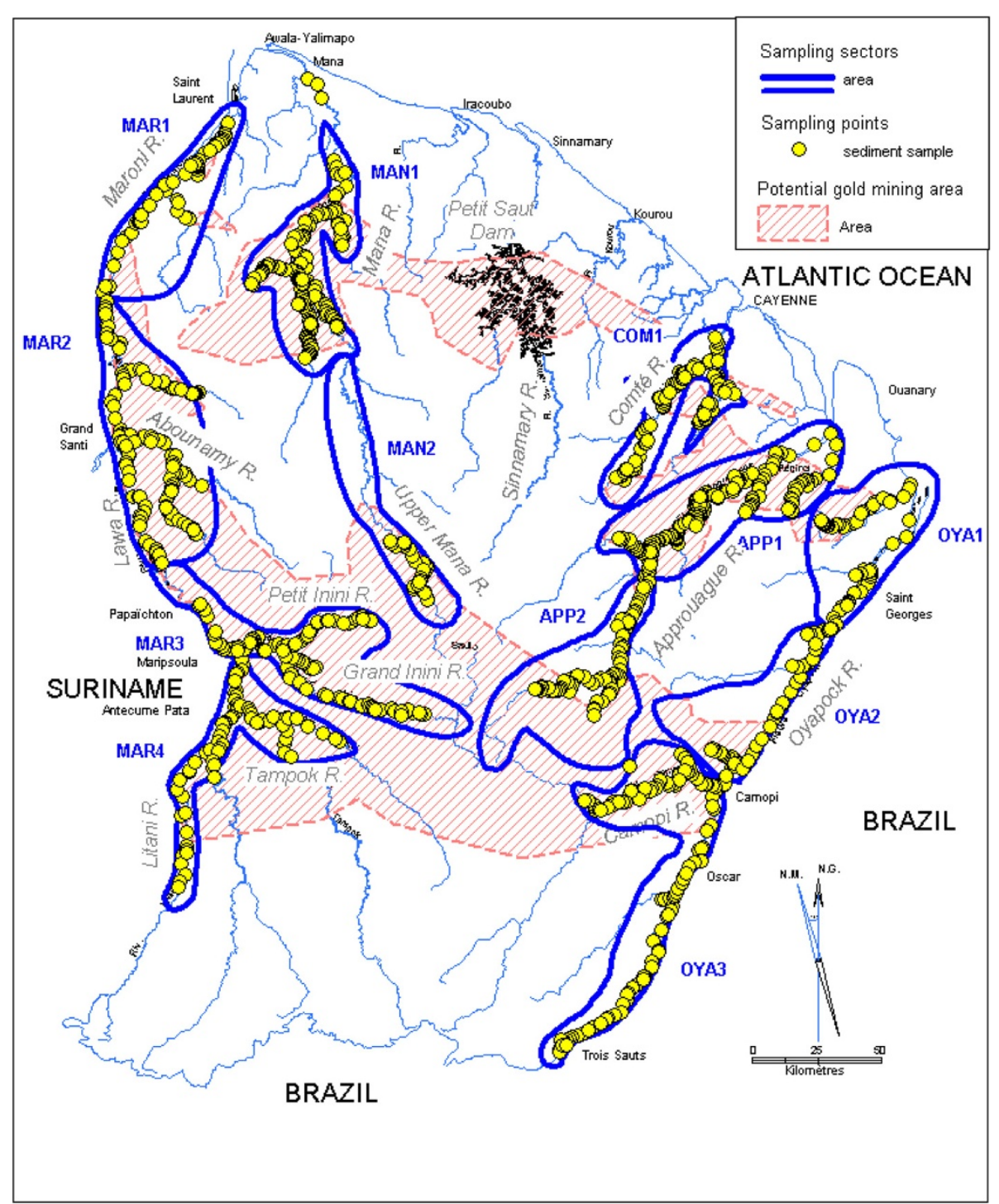

Figure 1 French Guiana map with sampling points, sampling sectors and the potential gold mining areas.

location of each of the sampling sites was recorded in the field with a GPS.

The different sampling steps aimed to evaluate i) the potential $\mathrm{Hg}$ sources: sampling downstream from the known gold mining sites, if possible with the up and downstream of these sites (1 km steps), and ii) $\mathrm{Hg}$ dispersion along the major drains: regular $5 \mathrm{~km}$ sampling step on the large rivers.

The watershed of the five rivers was cut into 12 sampling areas: Approuague River (APP 1 et 2), Comté River (COM 1), Mana River (MAN 1 et 2), Maroni River (MAR 1 à 4), Oyapock River (OYA 1 à 3) (Figure 1). The sampling areas were defined on the basis of logistic criteria (duration of the mission, oil autonomy, starting place and withdrawal), socio-politic criteria, and quality of the services (participation of the local communities).
At each sampling site, samples were collected from just above the low water line during low tide on river banks where finer sediment tends to accumulate. As these sediments were recently deposited during high tides, it is assumed that they provide geochemical information that reflects the last season's conditions. To eliminate the pieces of leaf and twigs, all the sediments collected with a stainless steel grab were passed through a $500 \mu \mathrm{m}$ sieve directly after sampling. None of the 1211 sediment samples collected contained coarse sand (500-2000 $\mu \mathrm{m})$. Samples were stored in polyethylene bottles and shipped to the laboratory in Orléans (France) within one or two weeks depending on the sampled area.

In order to sample all situations, different types of rivers were sampled: main rivers, their tributaries, medium rivers and streams (or creeks). Out of the 1211 samples, 
401 samples were collected on the banks of the main rivers (11 rivers are considered as main rivers: the large rivers such as Maroni, Mana, Comté, Approuague and Oyapock but also some of the large tributaries of these rivers such as Abounamy, Camopi, Tampok or Grand Inini). 327 samples were collected on the banks of the medium rivers (tributaries of the main rivers, 22 of which 8 have been gold mined); 241 were collected on the banks of gold-mined-streams and 242 on the banks of un-mined-streams.

Among the 1211 samples, 387 (1/3 of the total samples) were taken in rivers which waters were very turbid and 33 samples were taken in intertidal areas still under the influence of the Amazon River (Huynh et al. 1996).

\section{Analytical techniques}

All samples were homogenized and sub-samples were dried at $40^{\circ} \mathrm{C}$ in an oven then ground $(<80 \mu \mathrm{m})$ in an agate mortar before analysis. Total $\mathrm{Hg}$ was determined by AAS (Atomic Absorption Spectrometry) using a RA $915+$ equipped with the pyrolysis attachment (Lumex Society, Russia). All $\mathrm{Hg}$ results are given in $\mathrm{ng}$ of $\mathrm{Hg}$ per $\mathrm{g}$ of dry sediment (ng $\mathrm{g}^{-1}$ ).

Moisture was determined by weight loss in separate sub-samples by drying at $105^{\circ} \mathrm{C}$ overnight.

During the second mission on the Approuague River (APP2), water turbidity was measured with a field turbidimeter (TN100, Eutech) at each of the 80 sampling points. Turbidity is reported as Nephelometric Turbidity Units (NTU).

\section{Quality control of $\mathrm{Hg}$ determinations}

The drift in $\mathrm{Hg}$ determinations was followed every ten samples by analyzing standard reference material (Standard NCS DC78301 at $0.22 \pm 0.04 \mu \mathrm{g} \mathrm{g}^{-1} \mathrm{Hg}$ from the National Analysis Center, China and standard LGC6156 at $10.1 \pm 1.6 \mu \mathrm{g} \mathrm{g}^{-1} \mathrm{Hg}$ from the National Measurement Institute for chemical and bio analytical measurements, UK) to evaluate the analytical accuracy within $5 \%$. The reproducibility of the method was 3 to $5 \%$ except for concentrations between 250 and $1500 \mathrm{ng} \mathrm{kg}^{-1}$ where the reproducibility was 1.2 to $2.3 \%$.

About $10 \%$ of the samples were also analyzed by CVAFS in an independent laboratory (Chemex ALS, Canada) to control Lumex results.

\section{Statistical analysis}

Differences between $\mathrm{Hg}$ concentrations were determined with a nonparametric kruskal-Wallis test using the $\mathrm{R}$ software and pgirmess package ( $\mathrm{R}$ Development Core Team, 2004; Siegel and Castellan 1988).

\section{Results and discussion}

Textural classes of the sediment

Based on the revised textural classification scheme of gravel-free muddy sediment proposed by Flemming (2000) using the sand/mud ratios and the textural definition of mud as all sediments finer than $62.5 \mu \mathrm{m}$ (silt + clay), the 1211 sediments collected can be ranged in 5 classes (Table 1). Most of the sediments (87\%) have a texture between muddy sand and slightly sandy mud; not a single sample has a sandy texture.

\section{Background $\mathrm{Hg}$ concentrations}

Several studies (Roulet et al. 1998, Artaxo et al. 2000, Carmouze et al. 2002, Muresan 2006) have shown that $\mathrm{Hg}$ levels in Amazonian soils are high compared to temperate zones, mainly due to soil pedogenesis and high atmospheric depositions. Thus the soils constitute an important reservoir of naturally accumulated $\mathrm{Hg}$ that can be mobilized through naturel or anthropic erosion (deforestation, gold-mining) and induce increased export of terrestrial $\mathrm{Hg}$ to aquatic ecosystems.

Before looking at the regional distribution of $\mathrm{Hg}$ in river sediments of French Guiana, it is first important to evaluate the natural background levels of $\mathrm{Hg}$ ("natural background" is widely used to infer "background" levels reflecting natural processes uninfluenced by human activities; it is more realistic to view background as a range rather than an absolute value). The background level was evaluated from 51 samples collected on the Upper Oyapock (south of the Oscar's village, Figure 1). This part of the river and its tributaries are known to be free of alluvial gold mining activity. The mean $\mathrm{Hg}$ concentration in the muddy sediment of the Upper Oyapock is $100 \pm 30 \mathrm{ng} \mathrm{g}^{-1}$. This value is close to the one calculated from the 241 sediments collected in the un-gold-minedstreams (NGWS in Table 2) of the whole of French Guiana $\left(108 \pm 42 \mathrm{ng} \mathrm{g}^{-1}\right)$. It was not possible to estimate a background level for each NGMS because of the small number of data on some streams $(n=3)$; a background level was therefore calculated per sector. The background levels vary between $70 \pm 33 \mathrm{ng} \mathrm{g}^{-1}$ and $122 \pm 32 \mathrm{ng} \mathrm{g}^{-1}$ depending on geology and locality of the sector.

Table 1 Percentage of samples for the 6 textural classed based on mud content as defined by Flemming (2000)

\begin{tabular}{lcc}
\hline Mud content (\%) & Textural class & Samples (\%) \\
\hline$<5$ & Sand & 0.0 \\
$5-25$ & Slightly muddy sand & 7.1 \\
$25-50$ & Muddy sand & 29.3 \\
$50-75$ & Sandy mud & 31.3 \\
$75-95$ & Slightly sandy mud & 26.3 \\
$>95$ & Mud & 6.0 \\
\hline
\end{tabular}


Table 2 Mercury concentration statistics $\left(\mathrm{ng} \mathrm{g}^{-1}\right.$ ) calculated separately for the total data set, each main river, the No Gold Mined Streams (NGMS) and the Gold Mined Streams (GMS)

\begin{tabular}{|c|c|c|c|c|c|c|c|c|}
\hline $\mathrm{Hg}\left(\right.$ ng. g $\left.^{-1}\right)$ & French Guiana & Comté River & Approuague River & Mana River & Maroni River & Oyapock River & NGMS & GMS \\
\hline Minimum & 12 & 31 & 12 & 24 & 18 & 22 & 19 & 30 \\
\hline Maximum & $1320^{*}$ & 237 & $1320^{*}$ & 768 & 465 & 775 & 231 & 930 \\
\hline Median & 117 & 91 & 129 & 122 & 129 & 100 & 110 & 154 \\
\hline Medium & 152 & 98 & 238 & 143 & 139 & 114 & 108 & 190 \\
\hline$n^{1}$ & 1211 & 105 & 255 & 212 & 385 & 254 & 241 & 242 \\
\hline$\sigma$ & 438 & 45 & 85 & 100 & 69 & 937 & 42 & 137 \\
\hline
\end{tabular}

1: number of samples, ${ }^{*}$ maximum after removal of two aberrant values from the Approuague River $\left(10.05\right.$ and $\left.11.2 \mu \mathrm{g} \mathrm{g}{ }^{-1}\right)$.

These background values are on the same level of magnitude to the background levels measured by Charlet et al. (2003) on the Litani River $\left(109 \pm 30 \mathrm{ng} \mathrm{g}^{-1}\right)$ situated in the MAR4 sector and Roulet and Lucotte (1995) in French Guiana (180-320 $\mathrm{ng} \mathrm{g}^{-1}$ ). They are also comparable to other observations in the Amazonian basin such as the Madeira watershed (41-439 $\mathrm{ng} \mathrm{g}^{-1}$; Lechler et al. 2000), the Tapajos watershed (90-210 $\mathrm{ng} \mathrm{g}^{-1}$; Roulet et al. 1998) or the Rio Negro watershed (81-320 $\mathrm{ng} \mathrm{g}^{-1}$; Fadini and Jardim, 2001). Thus, the maximum value for the background level of $\mathrm{Hg}$ in sediment was estimated to be $150 \mathrm{ng} \mathrm{g}^{-1}$, except in the estuary areas where sediments have a low $\mathrm{Hg}$ level (around $50 \mathrm{ng} \mathrm{g}^{-1}$ ) due to the influence of Amazon deposits.

\section{Gold-mined versus non-gold-mined streams}

The average level in the NGMS $\left(108 \pm 42 \mathrm{ng} \mathrm{g}^{-1}\right)$, i.e. the background level, is significantly lower (Kruskal-Wallis, p-value $<0.001)$ and less variable than the Hg concentrations in sediments of the Gold Mined Streams (GMS), $\left(190 \pm 137 \mathrm{ng} \mathrm{g}^{-1}\right)$ (Table 2 and Figure 2).

Kruskal-Wallis tests were also run between the GMS and NGMS for each sub-sector and showed significant differences. Thus, data was grouped for each river sector and tests were repeated on this data (Figure 3). These results showed that whatever the region considered, there was always significantly higher $\mathrm{Hg}$ concentrations in the sediments from gold-mined streams compared to nongold-mined streams.

\section{Regional distribution of $\mathrm{Hg}$ concentrations in sediments} $\mathrm{Hg}$ concentrations in the samples ranged from 12 to 11 $200 \mathrm{ng} \mathrm{g}^{-1}$ (Table 2). $70 \%$ of the sediments have Hg concentrations lower than the maximal value of the background level: $150 \mathrm{ng} \mathrm{g}^{-1}$ (Figure 4). The 6 highest values were measured in sediments of the Approuague River 


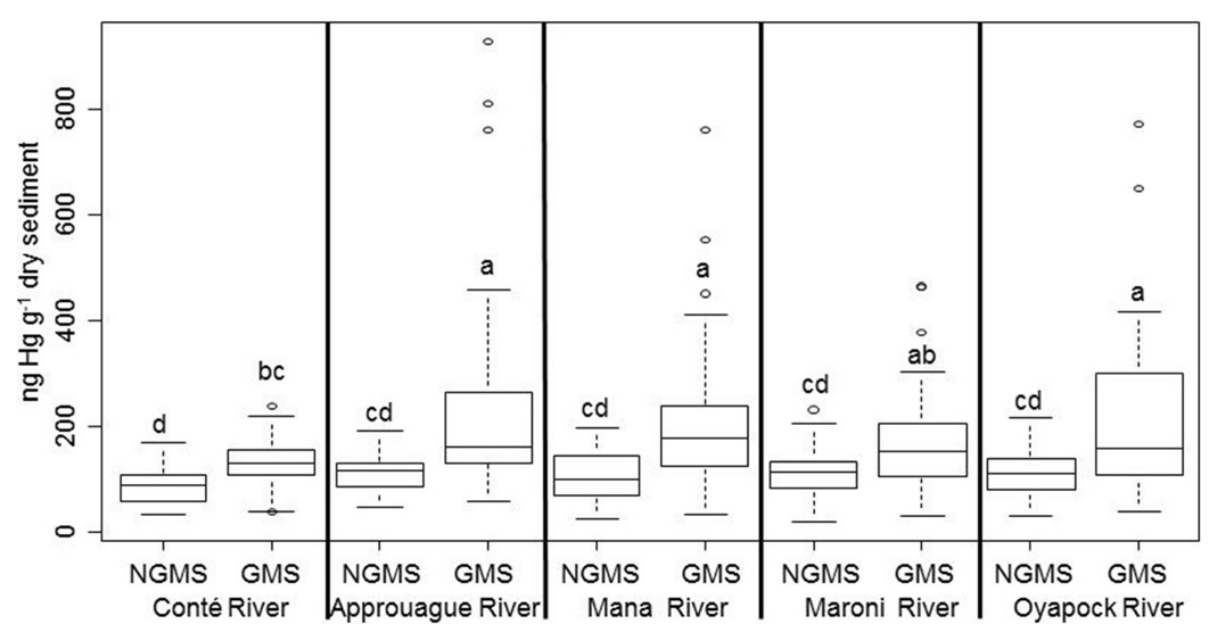

Figure 3 Boxplot comparing $\mathrm{Hg}$ contents in sediments from the gold-mined and non-gold-mined streams (GMS and NGMS) from the five main river sectors. Two aberrant points measured along the Approuague River were removed from the analysis (values of 10.05 and $11.2 \mathrm{\mu g} \mathrm{g}^{-1}$, respectively). Statistical differences between groups according to a Kruskal-Wallis test are indicated by the letters above the boxplots as well as the number or samples (n).

(810, 830, 930, 1320, 10050 and $11200 \mathrm{ng} \mathrm{g}^{-1}$ from "Impératrice", "Mataroni" and "Haut-Approuague" sectors). The minimal values, between 10 and $30 \mathrm{ng} \mathrm{g}^{-1}$ were measured for the Comté and Oyapock rivers in mud samples close to the estuary. For the other rivers, the sediments with low $\mathrm{Hg}$ levels were taken either in or just downstream from granitic areas. Significant differences (Kruskal-Wallis test $\mathrm{p}$-value $<0.001$ ) were shown between $\mathrm{Hg}$ concentrations in the Comté and Oyapock rivers and the other three main rivers (Mana, Maroni \& Approuague) which concentrations were globally higher by up to $40 \%$ (Figure 2, Table 2).

The whole dataset is presented on the map shown in Figure 4, where the results are presented by river sectors and not point by point. Each river sector covers one or a few fishing spots (max. 3), (Laperche et al., 2007) of a same catchment area.

The Oyapock River has been divided into five river sectors. (i) From Trois Sauts to the Yaloupi stream (south of Oscar's village: “Trois Sauts-Oscar" on Figure 4), the sector is free of gold mining activity and water of the Oyapock River was clear to clouded. Water was always clear in the tributaries of the Oyapock River (Moulou-moulou, Anapokéa and Yaloupi streams). Hg concentration in these sediments is always lower than $130 \mathrm{ng} \mathrm{g}^{-1}$ (Figure 4). (ii) From Yaloupi stream to Maripa village ("Oscar to Camopi"), the sector is, or was, gold mined towards the end of the $19^{\text {th }}$ century. At the time of sampling Camopi River was gold mined and several high values were measured on the mining sites (650 and $775 \mathrm{ng} \mathrm{g}^{-1}$ ). All the high values were found in sediments collected in turbid waters of GMS (Alicorne, Tampack and Alikéné). Thus it is possible to distinguish two types of streams:
- Streams with turbid to highly turbid water, downstream or close to the mines. Sediments are yellow to ochre and their $\mathrm{Hg}$ concentrations are between 200 and $800 \mathrm{ng} \mathrm{g}^{-1}$.

- Streams with clear to clouded water. Sediments are brown to grey and their $\mathrm{Hg}$ concentrations are lower than $150 \mathrm{ng} \mathrm{g}^{-1}$.

(iii) From Camopi to Maripa'village (south of Saint Georges: "Downstream Camopi"), the mean value is $94 \mathrm{ng} \mathrm{g}^{-1}$ but a few samples collected in the Oyapock River have higher $\mathrm{Hg}$ concentrations (up to $208 \mathrm{ng} \mathrm{g}^{-1}$ ). This sector is not gold mined anymore but up to 50 dredges were in activity until the eighties. (iv) From Maripa to the estuary ("Saint Georges"), this sector is not gold mined on the French side but it is slightly on the Brazilian side. The mean value is $97 \mathrm{ng} \mathrm{g}^{-1}$. They are lower in the north of Nouvelle Alliance $\left(<40 \mathrm{ng} \mathrm{g}^{-1}\right)$ but this zone corresponds to the limit of mud deposition from the Amazon River. (v) The Ouanary River is gold mined but $3 / 4$ of this river is under the influence of the tide; the major part of the sediments is mixed or covered with marine mud thus giving low $\mathrm{Hg}$ concentrations $\left(50 \pm 22 \mathrm{ng} \mathrm{g}^{-1}\right)$.

The Approuague River has been divided into six river sectors. (i) The Upper Approuague ("Haut Approuague") was much more gold mined in the past than nowadays. In this zone, the mean value is $142 \mathrm{ng} \mathrm{g}^{-1}$. Four samples have higher concentrations (up to $1320 \mathrm{ng} \mathrm{g}^{-1}$ close to Sapokai) that can be explained by the presence of dredges in the past. (ii) The zone between Sapokaï and the Machicou stream ("Sapokaye to Machicou") is granitic and the sediments have a $\mathrm{Hg}$ concentration close-to or lower-than the background level. (iii to v) The lower 


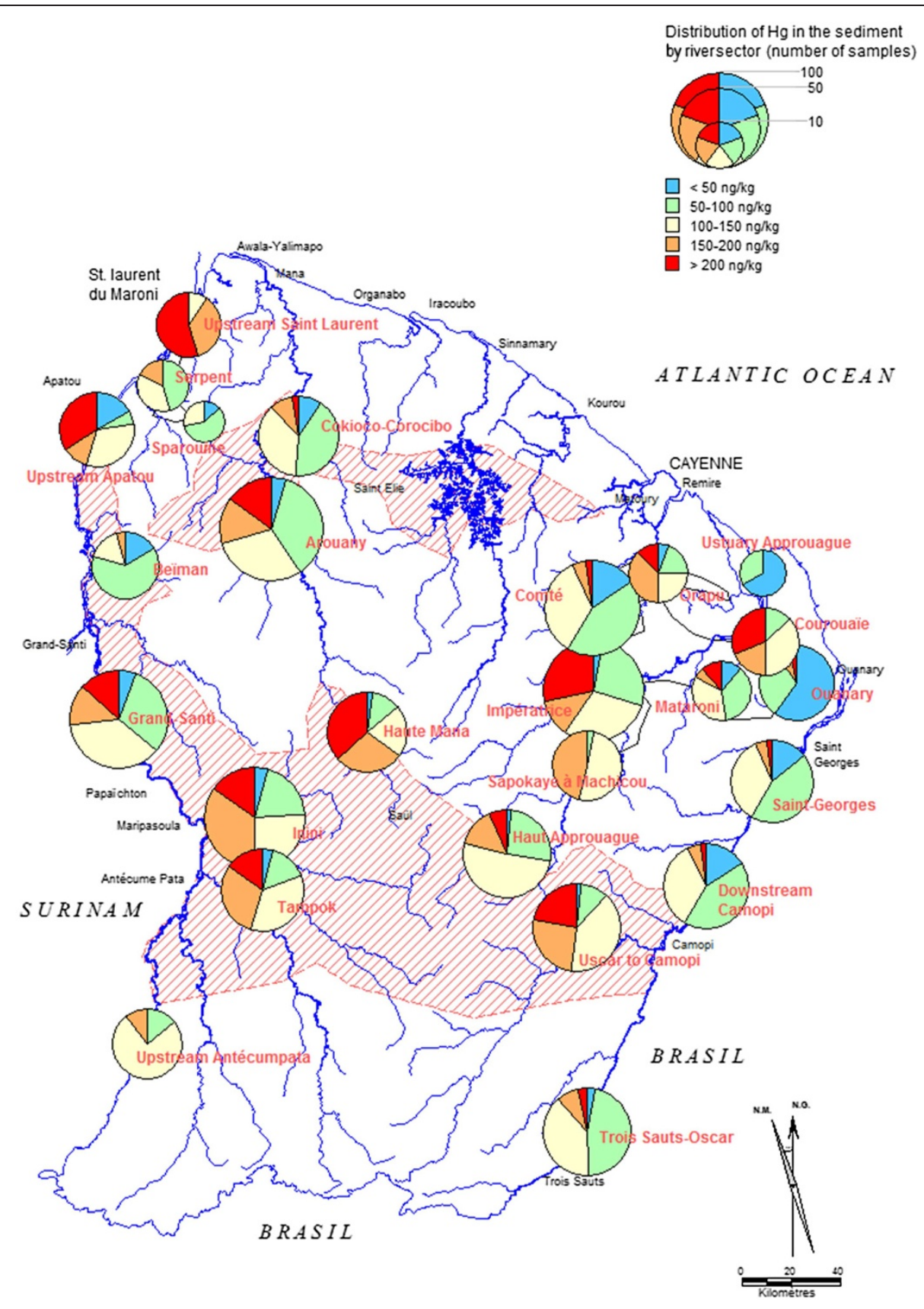

Figure 4 Distribution of $\mathrm{Hg}$ in sediments by river sector.

Approuague sector (Impératrice, Mataroni and Courouaie: "Impératrice") has been heavily gold mined since the end of the $19^{\text {th }}$ century, with numerous dredges. Indeed it is of the same geological formation as the Belizon mountain which is presently a large gold mining reserve. High $\mathrm{Hg}$ concentrations were found along the river; the 43 samples with a $\mathrm{Hg}$ concentration higher than $200 \mu \mathrm{g} \mathrm{g}{ }^{-1}$ represent $33 \%$ of the samples from this sector, whereas $14 \%$ of the samples from the whole territory have $\mathrm{Hg}$ concentrations higher than $200 \mu \mathrm{g} \mathrm{g}^{-1}$. The two highest $\mathrm{Hg}$ concentrations (>10 $000 \mathrm{ng} \mathrm{g}^{-1}$ ) were measured in sediments collected in the richest gold-nugget area of French Guiana (Impératrice); (vi) From Régina to Guisan bourg ("Approuague Estuary"), the area is not gold mined. The highest $\mathrm{Hg}$ concentration is $51 \mu \mathrm{g} \mathrm{g}^{-1}$ and it is lowest to the north $\left(<40 \mathrm{ng} \mathrm{g}^{-1}\right)$ where the river is under the influence of the tide and the Amazon River sediments.

The Comté sectors are composed by the Comté and the Orapu rivers. Hg concentrations are lower than the background level. The mean $\mathrm{Hg}$ concentration of sediments 
collected in the NGMS is much lower than the $\mathrm{Hg}$ concentration of sediments collected in the GMS (82 $\pm 39 \mathrm{ng} \mathrm{g}^{-1}$ and $134 \pm 55 \mathrm{ng} \mathrm{g}^{-1}$, respectively).

The Mana River can be divided into three river sectors separated by a granitic zone (Delor et al. 2001) not favorable for mud sampling (mostly pure quartz). (i) The Upper Mana ("Haute Mana") is a heavily gold mined area. The lowest $\mathrm{Hg}$ concentration is $98 \mathrm{ng} \mathrm{g}^{-1}$ and $75 \%$ of the samples collected in the Upper Mana have a Hg concentration higher than $177 \mathrm{ng} \mathrm{g}^{-1}$. (ii) The river sector of the lower Mana is also an area with much gold mining, in particular, the Arouani River ("Arouany") and (iii) the Mana River from the Arouani River to Cokioco and Corocibo rivers ("Cokioco-Corocibo"). The latter two rivers are slightly gold mined and the mean $\mathrm{Hg}$ concentrations in the sediments are $95 \pm 52 \mathrm{ng} \mathrm{g}^{-1}$ and $96 \pm 29 \mathrm{ng} \mathrm{g}^{-1}$, respectively. Upstream from the Arouani River, $\mathrm{Hg}$ concentrations are low $\left(<50 \mathrm{ng} \mathrm{g}^{-1}\right)$ but they increased rapidly downstream towards the placer "Délices" ( $\left.500 \mathrm{ng} \mathrm{g}^{-1}\right)$, one of the biggest placer of French Guiana.

$\mathrm{Hg}$ concentrations from the junction of the Mana River with the Cokioco River to the estuary remain high (110 \pm $36 \mathrm{ng} \mathrm{g}^{-1}$ ) compared to the estuaries of the other rivers. The Mana estuary is parallel (oriented NW-SE) to the coast, not perpendicular as for the other main rivers, and thus less favorable to marine mud deposition which dilutes continental $\mathrm{Hg}$-contaminated deposits.

The Maroni River (border between Suriname and French Guyana) is composed by 3 rivers: the Litany, the Lawa and the Maroni). From upstream to the estuary, many goldmined streams flow into the main rivers and many dredges are present on the rivers themselves. Therefore, the mean $\mathrm{Hg}$ concentrations increased from upstream to the estuary: from $128 \pm 30 \mathrm{ng} \mathrm{g}^{-1}$ (Litani River), to $169 \pm 63 \mathrm{ng} \mathrm{g}^{-1}$ (Lawa River) and $193 \pm 53 \mathrm{ng} \mathrm{g}^{-1}$ (Maroni River). (i) The river sector from "upstream to Antécum Pata" is not gold mined on the French side but it is gold mined on the Surinamese side (Oulemali River). Hg concentrations are lower than the Background. (ii) The river sectors of Maripasoula ("Tampok" et "Inini") with the Ouaqui, Grand Inini and Petit Inini rivers are gold mined $\left(235 \pm 70 \mathrm{ng} \mathrm{g}^{-1}\right)$.

(iii) The "Grand Santi" area is composed of the main rivers (Maroni and Lawa) and their tributaries Grand Abounamy and Petit Abounamy as well as their streams. A few dredges are present on the main river and $62 \%$ of the sediments have an $\mathrm{Hg}$ concentration higher than the Background level. (v) From the North of the Beïman River to the estuary ("Upstream Saint Laurent"), there are many dredges on the Maroni River (especially in the Apatou area) and $90 \%$ of the samples have a $\mathrm{Hg}$ concentration higher than the Background level. On the opposite, $7 \%$ of the sediments from former gold mined tributaries have a $\mathrm{Hg}$ concentration higher than the Background level ("Beïman", "Serpent" and "Sparouine" river sectors).

\section{Link between $\mathrm{Hg}$ concentrations and turbidity}

Most of the time, very turbid waters with ochre yellow colors are characteristic of upstream mining; it is therefore interesting to check if turbidity is actually correlated to $\mathrm{Hg}$ concentrations in sediments. This was carried out in 80 sampling spots. For example, during the second mission on the Approuague River, water turbidity was measured at each sampling point (Figure 5). On Calebasse creek, $\mathrm{Hg}$ concentrations in sediments are between 115 and $170 \mathrm{ng} \mathrm{g}^{-1}$ and the turbidity measurements are around 8 NTU. On Couata creek, turbidity measurements are much higher (290 to $470 \mathrm{NTU}$ ) but Hg sediment concentrations didn't increase proportionally (130 to $215 \mathrm{ng} \mathrm{g}^{-1}$ ). On Lomblin creek, turbidity measurements are around 50 NTU, higher than in the first stream, but $\mathrm{Hg}$ concentration in sediments is lower $\left(\sim 70 \mathrm{ng} \mathrm{g}^{-1}\right)$. The total turbidy database gave similar results (data not shown) to those on the Approuague. Thus it was not possible to establish a direct relationship between high $\mathrm{Hg}$ concentrations in sediments and sediment typology or water turbidity. Therefore, turbidity measurements are not a useful indicator of $\mathrm{Hg}$ contamination but are still a good indicator of the presence of active mines (Vigouroux et al. 2005).

For $7 \mathrm{~km}$ downstream from the Dorlin placer, one of the biggest placer of French Guiana, $\mathrm{Hg}$ concentrations in the sediment remained higher than $200 \mathrm{ng} \mathrm{g}^{-1}$. For the next $25 \mathrm{~km}$ until the Grand Inini River, they are between 200 and $150 \mathrm{ng} \mathrm{g}^{-1}$, and then along the following $25 \mathrm{~km}$ after the confluence of the two rivers, they are between 150 and $100 \mathrm{ng} \mathrm{g}^{-1}$. A similar decrease was observed downstream from « Dégrad Saint Léon », in the "Haute Mana" river sector on the Mana River. Here $\mathrm{Hg}$ concentrations start at $200 \mathrm{ng} \mathrm{g}^{-1}$, then decrease to $100 \mathrm{ng} \mathrm{g}^{-1}$ along the 5$6 \mathrm{~km}$ of the Mana River. In this case, all the streams flowing down the Mana River are not gold mined, but beyond the "Deux Branches" stream, $\mathrm{Hg}$ concentrations of the sedi-

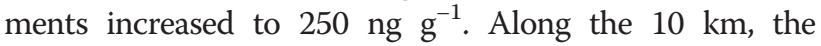
streams (Marc and Marie streams) flowing down the Mana River are gold mined. Thus, it is possible to follow a progressive decrease of $\mathrm{Hg}$ concentrations in sediment along the $5-7 \mathrm{~km}$ of the river. The impacted river length depends, amongst other things, on the size and activity of the mining placer upstream but also on the activity on the streams flowing down the main river. These values can be compared with those measured on the exploitation site of "Saint Elie" (Grimaldi et al. 2001). Hg concentrations in sediments upstream from the placer, in the vicinity of the site, and downstream are 127, 2489 and $549 \mathrm{ng} \mathrm{g}^{-1}$, respectively. There is an enrichment of $\mathrm{Hg}$ in the sediments downstream from the placers due to the transport of the finest particles.

All samples taken in rivers 20 or $30 \mathrm{~km}$ down from the placer do not show high $\mathrm{Hg}$ concentrations even if the waters are turbid as for the Sikini and the Lézard streams $\left(97 \pm 22 \mathrm{ng} \mathrm{g}^{-1}\right.$ and $69 \pm 15 \mathrm{ng} \mathrm{g}^{-1}$, respectively). 


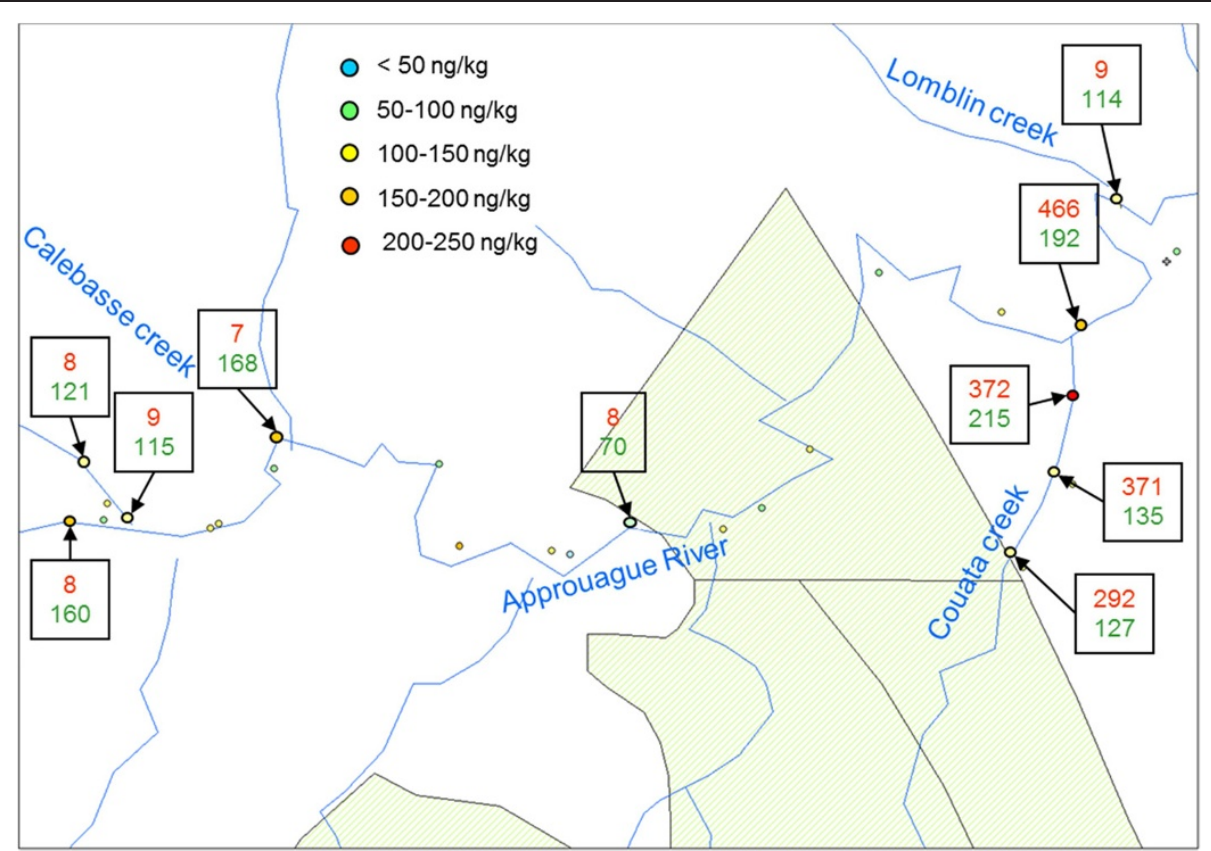

Figure 5 Comparaison of $\mathrm{Hg}$-sediment concentration and water turbidity along the Approuague River (in red: turbidity data in NTU and in green: $\mathrm{Hg}$ concentration in $\mathrm{ng} / \mathrm{kg}$ ).

\section{Conclusion}

The background $\mathrm{Hg}$ level in river sediments of the whole of French Guiana was estimated to be $108 \pm 42 \mathrm{ng} \mathrm{g}^{-1}$, depending on the mud/sand ratio. Around $70 \%$ of sediments have $\mathrm{Hg}$ concentrations lower than $150 \mathrm{ng} \mathrm{g}^{-1}$. An important point is the good correlation between the areas presenting high $\mathrm{Hg}$ concentrations (>150 $\mathrm{ng} \mathrm{g}^{-1}$ ) and the areas with strong gold bearing potential. In upstream areas such as "Trois Sauts " and " upstream Antecum Pata ", 89\% and $100 \%$ of $\mathrm{Hg}$ concentrations in sediments are lower than $150 \mathrm{ng} \mathrm{g}^{-1}$ whereas values $<150 \mathrm{ng} \mathrm{g}^{-1}$ represent only $65,50,48,45$ and $41 \%$ of samples in the gold mined areas "Haute Mana ", " Inini », « Camopi », « Tampok » and " Impératrice », respectively (Table 2 ).

The extensive data set collected in the present study enables typical configurations to be identified:

- gold mined areas (historical or present) with anomalous $\mathrm{Hg}$ concentrations (4-500 $\mathrm{ng} \mathrm{g}^{-1}$ to 10 $\left.000 \mathrm{ng} \mathrm{g}^{-1}\right)$;

- rivers and streams with ochre yellow sediments close to mined sites with high $\mathrm{Hg}$ concentrations (>200 ng g ${ }^{-1}$ );

- rivers and streams with brown to grey sediment with low $\mathrm{Hg}$ concentrations $\left(<150 \mathrm{ng} \mathrm{g}^{-1}\right)$;

- rivers close to the estuaries (marine sediment deposit areas) with very low $\mathrm{Hg}$ concentrations $\left(<60 \mathrm{ng} \mathrm{g}^{-1}\right)$;

- granitic areas (sandy sediment) with very low $\mathrm{Hg}$ concentrations (10 to $50 \mathrm{ng} \mathrm{g}^{-1}$ ).
The increase of $\mathrm{Hg}$ in sediment downstream from mining areas is clearly related to gold-mining activity. Besides $\mathrm{Hg}$ contamination, impacts of gold mining are numerous: deforestation, changes in river regime and ecology due to sedimentation and flow modification, changes in landform and visual intrusion, land degradation due to inadequate rehabilitation after closure, land instability... Roulet et al. (1998) and Grimaldi et al. (2008) have shown that Amazonian soils, including areas far from anthropic sources, are often highly concentrated in $\mathrm{Hg}$, therefore constituting an important reservoir of naturally accumulated $\mathrm{Hg}$. In comparison, the inputs from gold mining could represent less than $3 \%$ of the $\mathrm{Hg}$ present in the first $20 \mathrm{~cm}$ of the soil (Roulet et al. 1999). These studies suggest that throughout the river valley, erosion of fine particles from the soil cover is responsible for the increased export of terrestrial $\mathrm{Hg}$ to aquatic ecosystems. Soil erosion can be caused by disturbance of a land surface: building and road construction, slash and burn practices, mining... There is no data on the inputs from gold mining in deeper soil horizons of the historical placers. From the ratio $\mathrm{Hg} / \mathrm{Au}$ of 1.37, Picot et al. (1993), estimated the total $\mathrm{Hg}$ losses at $286 \mathrm{~T}$ in French Guiana $\left(60 \% \mathrm{Hg}_{\text {liq }}\right.$ and $40 \% \mathrm{Hg}_{\text {vap }}$ ) from 1857 to 2005 . It is possible to have punctually very high $\mathrm{Hg}$ levels in soil on the historical placers. Since 01/2006, it is forbidden to use $\mathrm{Hg}$ in French Guiana, but reworking these historical placers could liberate large amounts of $\mathrm{Hg}$. Gold mining dramatically increases soil erosion and the low settling rate of particles combined with their high $\mathrm{Hg}$ concentration 
implies a risk of $\mathrm{Hg}$ transfer to the hydrological network and the food chain (Boudou et al. 2006; Durrieu et al. 2005; Dominique 2006; Guédron 2008).

\section{Competing interests}

The authors declare that they have no competing interests.

\section{Authors' contributions}

VL co-coordinated the project, analyzed the data and drafted the manuscript; $\mathrm{JH}$ contributed to data analysis and manuscript drafting and revision; RMB contributed to field work; BJ and PL carried out the sampling campaigns; DB carried out mercury analyses and FB co-coordinated the project. All authors read and approved the final manuscript.

\section{Author details}

'BRGM, D3E, Water, Environment and Ecotechnology Division, 3 avenue Claude Guillemin, BP 36009, 45060 Orléans, France. ${ }^{2}$ UMR CNRS 5805 EPOC - OASU Station Marine d'Arcachon, Université Bordeaux 1, Place du Docteur Bertrand Peyneau, 33120 Archachon, France. ${ }^{3}$ French Geological Survey (BRGM), Direction régionale Guyane, Domaine de Suzini, Route de Montabo, BP 552, 97333 Cayenne cedex, France.

\section{Received: 4 February 2014 Accepted: 4 June 2014}

Published: 26 June 2014

\section{References}

Artaxo P, Calixto de Campos R, Fernandes ET, Martins JV, Xiao Z, Lindqvist O, Fernandez-Jimenez MT, Maenhaut W (2000) Large scale mercury and trace element measurements in the Amazon basin. Atmos Environ 34:4085-4096

Barbosa AC, Garcia AM, Souza JR (1997) Mercury contamination in hair of riverine populations of apiacás reserve in the Brazilian Amazon. Water Air Soil Pollut $97(1-2): 1-8$

Bidone ED, Castilhos ZC, Santos TJS, Souza TMC, Lacerda LD (1997) Fish contamination and human exposure to mercury in Tartarugalzinho River, Amapa State, Northern Amazon, Brazil. A screening approach. In: Brian W, Ron W, BillyM MC (ed) Mercury as a Global Pollutant. Human Health Issues, Springer Netherlands, pp 9-15

Boudou A, Ribeyre F (1997) Mercury in the food web: accumulation and transfer mechanisms. In: Sigel A, Sigel H (ed) Metal ions in biological systems Mercury and its effects on environment and biology. M. Dekker, New York, p 34. 289-315

Boudou A, Dominique Y, Cordier S, Frery N (2006) Les chercheurs d'or et la pollution par le mercure en Guyane française: conséquences environnementales et sanitaires. Environ Risques Santé 5:167-179

Carmouze JP, Lucotte M, Boudou A (2002) Le mercure en Amazonie, rôle de I'homme et de l'environnement, risques sanitaires. IRD Editions, Paris, France

Castilhos ZC, Bidone ED, Lacerda LD (1998) Increase of the background human exposure to mercury through fish consumption due to gold mining at the Tapajós River Region, Pará State, Amazon. Bull Environ Contam Toxicol 61(2):202-209

Charlet L, Roman-Ross G, Spadini L, Rumbach G (2003) Solid and aqueous mercury in remote river sediments (Litani River, French Guyana, South America). J Phys 107(1):281-284. IV, XIlth International Conference on Heavy Metals in the Environment. Proceedings: Grenoble, France, May 26-30, 2003 Collectif (2002) Atlaseco du Monde, Mediaobs ed, p 329

Compeau G, Bartha R (1985) Sulfate reducing bacteria: principal methylators of $\mathrm{Hg}$ in anoxic estuarine sediments. Appl Environ Microbiol 50:498-502

Cordier S, Grasmick C, Pasquier-Passelaigue M, Mandereau L, Weber JP, Jouan M (1997) Imprégnation de la population guyanaise par le mercure: niveaux et sources d'exposition. BEH 14:59-61

Delor C, Lahondère D, Egal E, Marteau P (2001) Carte géologique de la France: carte géologique de la Guyane (1/500 000), BRGMth edition

Dominique $Y$ (2006) Contamination par les différentes formes chimiques du mercure de la composante biologique du barrage hydroélectrique de Petit-Saut et des zones amont/aval du fleuve Sinnamary, en Guyane française (études in situ et approches expérimentales). Thèse Université de Bordeaux I, p 366

Durrieu G, Maury-Brachet R, Boudou A (2005) Goldmining and mercury contamination of the piscivorous fish hoplias aimara in French Guiana (Amazon Basin). Ecotoxicol Environ Saf 60(3):315-323. 2005

Fadini PS, Jardim WF (2001) Is the Negro River Basin (Amazon) impacted by naturally occurring mercury? Sci Total Environ 275:71-82
Fleming EJ, Mack EE, Green PG, Nelson CN (2006) Mercury methylation from unexpected sources: molybdate-inhibited freshwater sediments and iron-reducing bacterium. Appl Environ Microbiol 72:457-464

Flemming BW (2000) A revised textural classification of gravel-free muddy sediments on the basis of ternary diagrams. Cont Shelf Res 20:1125-1137

Grimaldi M, Gaudet JP, Grimaldi C, Melieres MA, Spadini L (2001) In programme mercure en Guyane du CNRS-PEVS, volet sols. Sources, stocks et transfert dans les sols et sédiments, Final report, $1^{\text {st }}$ part, pp 4-35

Grimaldi C, Grimaldi M, Guedron S (2008) Mercury distribution in tropical soil profiles related to origin of mercury and soil processes. Sci Total Environ 401:121-129

Guédron S (2008) Impact de l'exploitation miniere en guyane française sur les flux de mercure vers Les écosystemes aquatiques. Thèse Université Joseph Fourier, Grenoble I, p 322

Huynh F, Charron C, Bétoulle JL, Baltzer F, Prost MT (1996) Etude suivi de l'évolution géomorphologique et botanique de l'estuaire du Sinnamary par télédétection : rapport intermédiaire R1 juillet 1995. In: Grégoire A (ed) Actes des sixièmes journées "Environnement" relatives à la protection du site de Petit Saut (Guyane). Sinnamary : EDF-CNEH, 1996, 24 p. multigr. Journées Environnement, 6., Sinnamary (GUF), 1995/06/21-22

King JK, Harmon SM, Fu TT, Gladden JB (2002) Mercury removal, methylmercury formation, and sulfate-reducing bacteria profiles in wetland mesocosms. Chemosphere 46:859-870

Laperche V, Maury-Brachet R, Blanchard F, Dominique Y, Durrieu G, Massabuau JC, Bouillard H, Joseph B, Laporte P, Mesmer-Dudons N, Duflo V, Callier L (2007) Répartition régionale du mercure dans les sédiments et les poissons de six fleuves de Guyane - Rapport BRGM/RP-55965-FR, BRGMth edition, p 200

Lechler PJ, Miller JR, Lacerda LD, Vinson D, Bonzongo JC, Lyons WB, Warwick JJ (2000) Elevated mercury concentrations in soils, sediments, water, and fish of the Madeira River basin, Brazilian Amazon: a function of natural enrichments. Sci Total Environ 260(1-3, 9):87-96

Mason RP, Fitzgerald WF, Morel FMM (1994) The biogeochemical cycling of elemental mercury: anthropogenic influences. Geochim Cosmochim Acta 58(15):3191-3198

Maury-Brachet R, Durrieu G, Dominique Y, Boudou A (2006) Mercury distribution in fish organs and food regimes: significant relationships from twelve species collected in French Guiana (Amazonian basin). Sci Total Environ 368:262-270

Milesi JP, Egal E, Ledru P, Vernhet Y, Thieblemont D, Cocherie A, Tegyey M, Martel-Jantin B, Lagny PH (1995) Les minéralisations du Nord de la Guyane française dans leur cadre géologique: chronique de la Recherche Minière, BRGM (ed), vol 518, pp 5-58

Morel FMM, Kraepiel AML, Amyot M (1998) The chemical cycle and bioaccumulation of mercury. Annu Rev Ecol Syst 29:543-566

Muresan B (2006) Mercury geochemistry in the continuum of Petit Saut reservoir and the Sinnamary estuary, French Guiana (in French). P.H.D Thesis. University of Bordeaux I, PhD Thesis, p 264

De Oliveira SMB, Melfi AJ, Fostier AH, Forti MC, Favaro DIT, Boulet R (2001) Soils as an Important Sink for Mercury in the Amazon, Water. Water Air Soil Pollut 26:321-337

Picot JC, Foucher JL, Wagner R (1993) Production aurifère et mercure utilisé de I'origine à nos jours. Rapport BRGM-R37837, BRGM (ed). p 154

Quenel P, Saviuc P, et Godard E (2007) Le mercure en Guyane : risque sanitaire et enjeux de santé publique. In: InVS, Cire Antilles Guyane (ed) BASAG «Bulletin d'Alerte et de Surveillance Antilles Guyane», vol 7, p 16

R Development Core Team (2004) R: A language and environment for statistical computing. R Foundation for Statistical Computing, Vienna, Austria. http://www.R-project.org. ISBN 3-900051-07-0

Roulet M, Lucotte M (1995) Geochemistry of mercury in pristine and flooded ferralitic soils of a tropical rain forest in French Guiana, South America. Water Air Soil Pollut 80:1079-1088

Roulet M, Lucotte M, Saint-Aubin A, Tran S, Rhéault I, Farella N, De Jesus DA, Silva E, Dezencourt J, Sousa Passos CJ, Santos Soares G, Guimaraes JRD, Melger D, Amorim M (1998) The geochemistry of $\mathrm{Hg}$ in central amazonian soils developed on the Alter-do-Chão formation of the lower Tapajòs river valley, Pará state Brazil. Sci Total Environ 223(1):297-313

Roulet M, Lucotte M, Farella N, Serique G, Coelho H, Sousa Passos CJ, De Jesus Da Silva E, Scavone De Andrade P, Mergler D, Guimaraes JR, Amorim M (1999) Effects of recent human colonization on the presence of mercury in Amazonian ecosystems. Water Air Soil Pol I 112(3-4):297-313

Sampaio Da Silva D, Lucotte M, Paquet S, Davidson R (2009) Influence of ecological factors and of land use on mercury levels in fish in the Tapajós River Basin, Amazon. Environ Res 109(4):432-446 
Schuster E (1991) The behavior of mercury in the soil with special emphasis on complexation and adsorption processes. A review of the literature. Water Air Soil Poll 56:667-680

Siegel S, Castellan NJ (1988) Non parametric statistics for the behavioural sciences. MacGraw Hill. Int, New York, pp 213-214

Silva-Forsberg MC, Forsberg BR, Zeidemann VK (1999) Mercury contamination in humans linked to river chemisry in the Amazon basin. Ambio 28(6):519-521

Ullrich SM, Tanton TW, Abdrashitova SA (2001) Mercury in the aquatic

environment: a review of factors affecting methylation. Crit Rev Environ Sci Technol 31:241-293

Veiga MM, Meech JA, Beinhoff CA (1999) Mercury in Artisanal Gold Mining: Myths, Facts and Solutions. In: Proc. 5th Int. Conference on Mercury as a Global Pollutant. Rio de Janeiro, p 497. May 23-28, 1999 (abstract)

Vigouroux R, Guillemet L, Cerdan PH (2005) Etude de l'impact de l'orpaillage alluvionnaire sur la qualité des milieux aquatiques et la vie piscole. Etude et mesure de la qualité physico-chimique des eaux de l'Approuague au niveau de la Montagne Tortue et son impact sur les populations de poissons et d'invertébrés aquatiques. Rapport Hydréco-DAF, HYDRECO (ed), p 40

Voicu G, Bardoux M, Stevenson R (2001) Lithostratigraphy, geochronology and gold metallogeny in the northern Guiana Shield, South America: a review. Ore Geol Rev 18:211-236

Weng P, Aulong S, Dolbeau X, Guillet J, Orru JF, Saget M (2006) Mise en oeuvre de la Directive Cadre Européenne sur l'Eau : District de la Guyane - Plan détaillé d'état des lieux. Plan détaillé d'état des lieux. Rapport BRGM/RP54630-FR. BRGM (ed). p 143

World Health Organisation (WHO) (1990) Environmental health criteria, 101 methylmercury. WHO/IPCS, Geneva, Switzerland

doi:10.1186/2193-1801-3-322

Cite this article as: Laperche et al: Regional distribution of mercury in sediments of the main rivers of French Guiana (Amazonian basin).

SpringerPlus 2014 3:322.

\section{Submit your manuscript to a SpringerOpen ${ }^{\circ}$ journal and benefit from:}

- Convenient online submission

- Rigorous peer review

- Immediate publication on acceptance

- Open access: articles freely available online

- High visibility within the field

- Retaining the copyright to your article

Submit your next manuscript at $\gg$ springeropen.com 